Egyptian Journal of Aquatic Biology \& Fisheries

Zoology Department, Faculty of Science,

Ain Shams University, Cairo, Egypt.

ISSN $1110-6131$

Vol. 25(1): 935 - 952 (2021)

www.ejabf.journals.ekb.eg

\title{
Estimation of Relative Growth of Anabas testudineus through multiple linear dimensions
}

\author{
Zannatul Mawa $^{1}$, Sumaya Tanjin ${ }^{1}$, Md. Yeamin Hossain ${ }^{1,4}$, Md. Rabiul Hasan ${ }^{1}$, \\ Md. Ashekur Rahman ${ }^{1}$, Wasim Sabbir ${ }^{2}$, Md. Abul Kalam Azad ${ }^{1}$, Md. Akhtarul Islam ${ }^{1}$, \\ Md. Ataur Rahman ${ }^{1}$, Saleha Jasmine ${ }^{1}$, Zahra Basir ${ }^{3}$, Most. Shakila Sarmin ${ }^{1}$ and Jun Ohtomi ${ }^{4}$ \\ ${ }^{1}$ Department of Fisheries, Faculty of Agriculture, University of Rajshahi, Bangladesh \\ ${ }^{2}$ Fisheries and marine Resource Technology Discipline, Khulna University, Bangladesh \\ ${ }^{3}$ Department of Basic Sciences, Faculty of Veterinary Medicine, Shahid Chamran University of \\ Ahvaz, Ahvaz, Iran \\ ${ }^{4}$ Faculty of Fisheries, Kagoshima University, 4-50-20 Shimoarata, Kagoshima 890-0056, Japan \\ *Corresponding author: hossainyeamin@gmail.com; yeamin.fish@ ru.ac.bd
}

\begin{abstract}
ARTICLE INFO
Article History:

Received: Sept. 10, 2020

Accepted: Jan. 30, 2021

Online: Feb. 28, 2021

Keywords:

Anabas testudineus,

length-weight

relationships,

length-length

relationships,

fin formula,

Gajner Beel,

wetland ecosystem.
\end{abstract}

\section{ABSTRACT}

This study provides scientific investigation on the relative growth pattern based on multiple linear dimensions and also observed the meristic characteristics of Anabas testudineus from the Gajner Beel northwestern (NW) Bangladesh from July to December 2018. A total of 454 individuals were collected and lengths and weight were noted up to $0.01 \mathrm{~cm}$ and $0.01 \mathrm{~g}$ precision using a measuring board and digital weight balance, respectively. Fin rays and lateral line scales were counted by using a magnifying glass. Total length (TL) was ranged 7.40-14.50 cm while body weight (BW) ranged 7.90-64.00 g. Relationships of length-weight (LWRs) were highly significant $(p<0.001)$ with $r^{2}$ values $\geq 0.823$. TL $v s$. BW was one of the best models among ten equations based on $r^{2}$ value in LWR. In comparison, length-length relationships (LLRs) were extremely important $(p<0.001)$ and most of the $r^{2}$ values were greater than 0.844 . In LLR, SL vs. TL and PoAnL was the fitted model according to $r^{2}$ value among nine equations. Fin formula of $A$. testudineus was D. 26-28 (XVI-XVIII 1-2/7-10) $\mathrm{P}_{1}$. 13-15 (1-2/11-14) $\mathrm{P}_{2} .6$ (I5) A. 18-21 (VIII-XI1 2/8-10) C. 15-17 (2/13-15).The results of this study will keep a vital contribution to stock assessment and sustainable management for A. testudineus in this wetland ecosystem and other world wide water bodies.

\section{INTRODUCTION}

Anabas testudineus (Bloch, 1792) is an exceedingly costly freshwater fish species belonging to the order Perciformes and the family Anabantidae (Marimuthu et al., 2009; Khatun $\boldsymbol{e t}$ al., 2019). This order comprises seven families containing at least 252 species (Collins et al., 2015; Nelson et al., 2016). The family Anabantidae comprising about 33 species in 4 genera (Froese and Pauly, 2019) possess a labyrinth organ i.e., accessory 
air-breathing organ (Alleng, 1991; Khatun et al., 2019 ) which allows it to breathe atmospheric oxygen (Rahman, 1989) and can survive out of water for a long period of time also make them able to resist poor water condition (Atack, 2006). It is commonly called a climbing perch due to its ability to walk on land (Talwar and Jhingran, 1991). A. testudineus locally known as 'koi' in Bangladesh and India, pla mor thai in Thailand, puyo in Philippine, kavaiya in Sri Lanka is a bottom dweller and insectivorous fish (Foresee and Pauly, 2020). It is extensively distributed in Bangladesh, India, Pakistan, Sri Lanka, Burma, Singapore, Malay Archipelago, Philippines, Indonesia, southern China and Taiwan (Rainboth, 1996; Wang et al., 1999; Kottelat, 2001, Tan and Lim, 2004). This species inhabits both in fresh water and brackish water mostly found in beels, canals, lakes, ponds, swamps, haors, ditches, floodplains, baors and estuaries (Talwar and Jhingran, 1991; Menon, 1999; Vidthayanon, 2002). A. testudineus is an omnivorous fish primarily dependent on organic debris algae, crustaceans, insects, worms, molluscs and soft plant parts (Nagris and Hossain, 1987; Pandey et al., 1992; Prasanth, 2006). The species contains a huge amount of iron and copper, which are essentially required for hemoglobin synthesis. It is a reasonable source of protein in Southeast Asian states like Bangladesh and Malaysia (Alam et al., 2010; Zalina et al., 2011). Anabas can survive in temperature fluctuations, low $\mathrm{pH}$ and low dissolved ox ygen (Kohinoor et al., 2009; Sarma et al., 2010; Be et al., 2017).Overfishing, Pollution, and wetland conversion may possibly threaten to it (Hossain et al., 2015a). A. testudineus is listed as least concerned (LC) in Bangladesh (IUCN Bangladesh, 2015) and data deficient species according to IUCN (2020) for worldwide water bodies.

A land, which is inundated by water, annually or seasonally, permanently or temporarily that is called wetland (Keddy, 2010). The wetlands can be freshwater, brackish, or saltwater (Ramsar conservation, 1971). Gajner Beel is situated at Sujanagar, Pabna in the northwestern (NW) Bangladesh. This Beel used as an imperative feeding and spawning ground by many freshwater fish species. Near about 0.5 million people of surrounding villages of this Beel are directly or indirectly reliant on this wetland for their livelihood (Mazid et al., 2005).

Regression analysis is the one of the statistics analysis that used to explore and modeling the relationship between variables. Multiple linear regressions are the method of statistics in regression that used to analyze the relationship between single response variable (dependent variable) with two or more controlled variables (independent variables) (Ghani and Ahmed, 2011).

Fish length is often considered more significant than fish age, as many ecological and physiological factors depend more on the length than the age (Erzini et al., 1997). Length-length (L-L) relationships of fishes are essential in management for relative growth studies (Sandoval-Huerta et al., 2015). In that case, where only lengths data are available we can easily estimate the weight and biomass by using (Park and Huh, 2015) and LWRs also help in conservation and control of wild populations and also for observing the well-being of fishes (Hossain et al., 2012a; Hassan et al., 2020; Hasan et al., 2020) Further, the knowledge about growth pattern is essential for different studies in biology, physiology, and ecology of the natural and commercially exploited population of fishes (Czerwinski et al., 2008). Meristic study relates to count the quantitative characteristics of fish, such as the number of fins or scales (Islam $\boldsymbol{e t}$ al., 2020). In addition, meristics and morphometrics features have been used to identify stocks of fish, 
differentiate the species taxonomically, and distinct various morpho types (Lourie et al., 1999; Doherty and McCarthy, 2004; Jayasankar et al., 2004; Islam et al., 2020). However, morphometric characters are less heritable than meristic characters (Beacham, 1990; Islam et al., 2020) that's why morphometric features were the more preferred method to identifying intraspecific deviation within a stock (Murphy et al., 2007).

Therefore, a very few works have been dedicated on growth of A. testudineus from worldwide water bodies that were given in Table 1. There is no existing info on estimating relative growth of A. testudineus from the Gajner Beel on the basis of morphometric and meristic features. This study was therefore undertaken to investigate the relative growth of $A$. testudineus populations inhabiting the Gajner Beel, NW Bangladesh using multiple linear dimensions.

Table 1. Available literature on Anabas testudineus from worldwide water bodies.

\begin{tabular}{|c|c|c|}
\hline Aspects & Water body & Reference \\
\hline $\begin{array}{l}\text { Length-weight relationship and } \\
\text { condition factor }\end{array}$ & Kausalyaganga, Orissa, India & $\begin{array}{l}\text { Kumar et al. } \\
\text { (2013) }\end{array}$ \\
\hline Length- weight relationship & Tetulia River, Bangladesh & $\begin{array}{l}\text { Hossain et al. } \\
(2015 b)\end{array}$ \\
\hline $\begin{array}{l}\text { Morphometrical and gonadal } \\
\text { studies }\end{array}$ & West Bengal, India & $\begin{array}{l}\text { Ziauddin et al. } \\
(2016)\end{array}$ \\
\hline $\begin{array}{l}\text { Length-weight relationship and } \\
\text { relative condition factor }\end{array}$ & $\begin{array}{l}\text { Deepar Beel (wetland), Assam, } \\
\text { India }\end{array}$ & $\begin{array}{l}\text { Rahman et al. } \\
\text { (2015) }\end{array}$ \\
\hline $\begin{array}{l}\text { Length-weight relationship and } \\
\text { Species composition }\end{array}$ & Candaba wetland, Philippines & Garcia (2010) \\
\hline $\begin{array}{l}\text { Growth and morphological } \\
\text { development }\end{array}$ & Vientiane City, Laos & $\begin{array}{l}\text { Morioka et al. } \\
\text { (2009) }\end{array}$ \\
\hline $\begin{array}{l}\text { Length-weight and length- } \\
\text { length relationships }\end{array}$ & Chi River, thailand & $\begin{array}{l}\text { Satrawaha and } \\
\text { Pilasamorn } \\
(2009)\end{array}$ \\
\hline Fecundity & Kedah, Malaysia & $\begin{array}{l}\text { Marimuthu et al. } \\
\text { (2009) }\end{array}$ \\
\hline $\begin{array}{l}\text { Stocking density, growth and } \\
\text { production }\end{array}$ & Mymensingh, Bangladesh & $\begin{array}{l}\text { Jannat et al. } \\
(2012)\end{array}$ \\
\hline $\begin{array}{l}\text { Length weight relationships and } \\
\text { condition factor }\end{array}$ & $\begin{array}{l}\text { Semayang Lake, East } \\
\text { Kalimantan, Indonesia }\end{array}$ & $\begin{array}{l}\text { Mustakim et al. } \\
\text { (2019) }\end{array}$ \\
\hline
\end{tabular}

\section{MATERIALS AND METHODS}

\section{Fish sampling}

A total number of 454 specimens of $A$. testudineus were collected occasionally from the Gajner Beel, a wetland ecosystem, NW Bangladesh (Fig.1) during July to 
December 2018 through cast net (mesh size, $2.5 \mathrm{~cm}$ ). These samples were stored as soon as possible with $10 \%$ buffered solution for the further process.

\section{Fish measurements}

Digital electronic balance was used to take body weight (BW) of the sample to the nearest $0.01 \mathrm{~g}$ accuracy. The morphometric characters i.e., ten different lengths (Fig. 2) were measured following Hubbs and Lagler (1958) with slight modification by digital slide calipers to the nearest $0.01 \mathrm{~cm}$ accuracy.

\section{Growth pattern}

LWRs were estimated by the model; $\mathrm{W}=\mathrm{a} \mathrm{L}^{b}$. LLRs were also assessed by linear regression analysis (Le Cren, 1951).

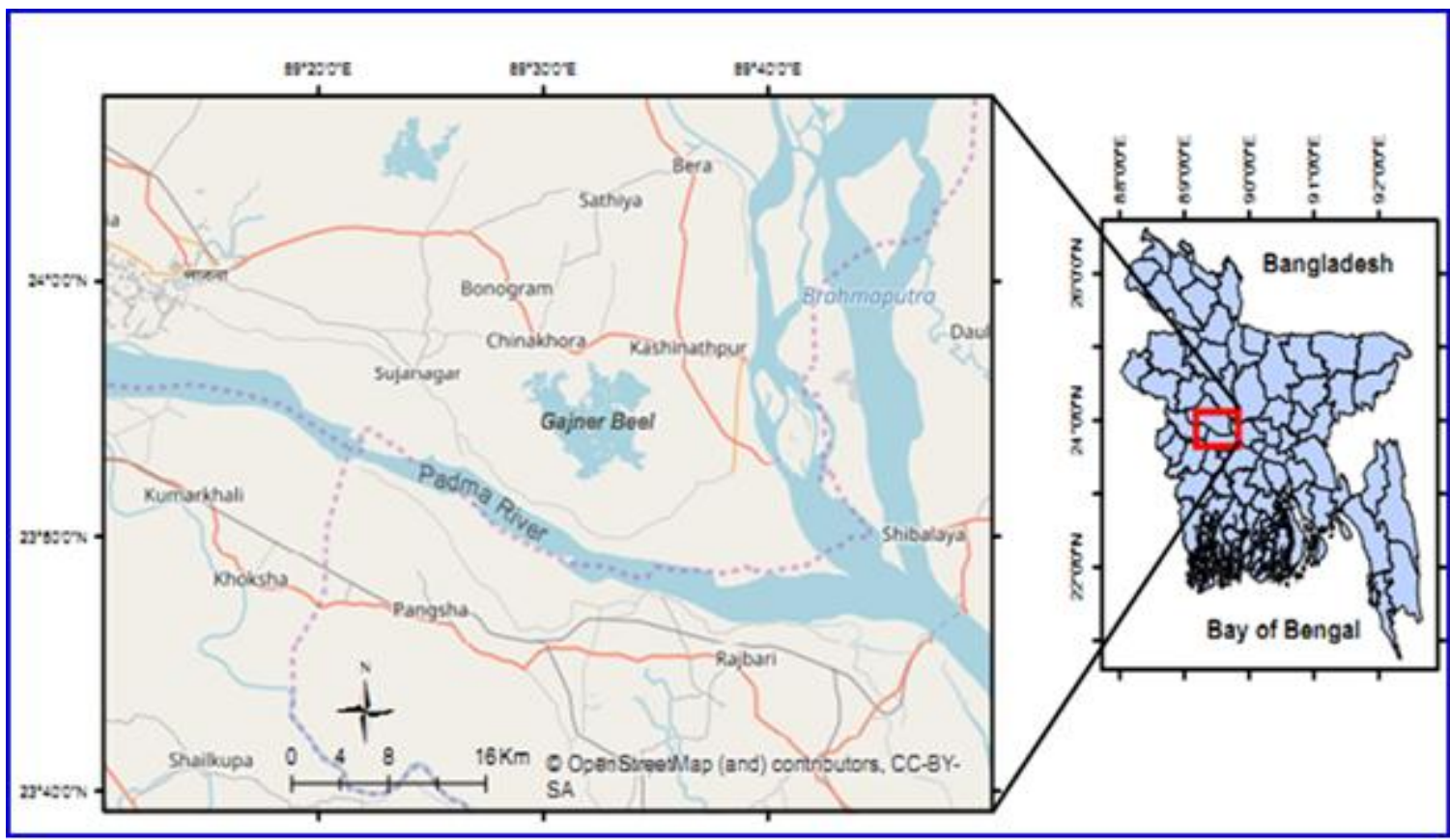

Fig. 1. Sampling sites in the Gajner Beel (indicated by red circle), northwestern Bangladesh.

\section{Meristic counts}

A magnifying glass was used to count the number of fin rays and scale (lateral line).

\section{Statistical analyses}

All statistical analyses were completed through the GraphPad Prism 6.5 software and Microsoft Excel program with consideration of $5 \%$ significant level. 


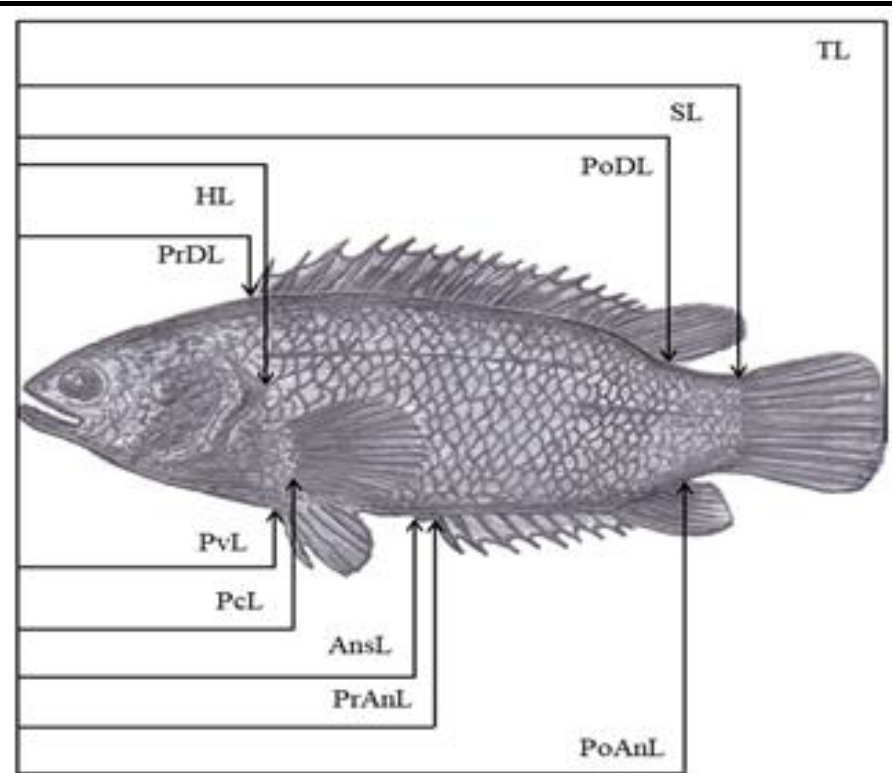

Fig. 2. Showing the morphometric measurements of Anabas testudineus from the Gajner Beel.

\section{RESULTS}

\section{Growth pattern}

In our study, total length (TL) was varied within 7.40-14.50 cm (mean $\pm \mathrm{SD}$, $10.88 \pm 1.39)$ and BW was 7.89-64.00 g (26.52 \pm 10.68$)$ (Table 2).

Table 2. Descriptive statistics of Anabas testudineus $(n=454)$ captured from the Gajner Beel, NW Bangladesh

\begin{tabular}{|lccccccc|}
\multicolumn{1}{|c}{ Measurements } & $\begin{array}{c}\text { Min } \\
(\mathbf{c m})\end{array}$ & $\begin{array}{c}\text { Max } \\
(\mathbf{c m})\end{array}$ & $\begin{array}{c}\text { Mode } \\
(\mathbf{c m})\end{array}$ & Mean \pm SD & 95\% CL (cm) & $\begin{array}{c}\text { \% } \\
\text { TL }\end{array}$ \\
\hline TL (Total length) & 7.40 & 14.50 & 9.80 & $10.88 \pm 1.39$ & 10.70 to 11.05 & 100 \\
\hline SL (Standard length) & 6.10 & 11.90 & 8.00 & $8.6 \pm 1.11$ & 8.52 to 8.80 & 82.07 \\
\hline HL (Head length) & 1.70 & 3.60 & 2.90 & $2.73 \pm 0.34$ & 2.69 to 2.78 & 24.83 \\
\hline PrDL (Pre-dorsal length) & 1.90 & 4.30 & 3.10 & $2.99 \pm 0.42$ & 2.94 to 3.04 & 29.66 \\
\hline $\begin{array}{l}\text { PoDL(Post-dorsal } \\
\text { length) }\end{array}$ & 5.20 & 10.40 & 8.10 & $7.81 \pm 1.02$ & 7.68 to 7.94 & 71.72 \\
\hline PcL (Pectoral length) & 2.10 & 4.00 & 3.00 & $2.98 \pm 0.33$ & 2.94 to 3.02 & 27.59 \\
\hline PvL (Pelvic length) & 2.30 & 4.60 & 3.20 & $3.28 \pm 0.43$ & 3.23 to 3.34 & 31.72 \\
\hline AnsL (Anus length) & 3.10 & 6.50 & 4.60 & $4.65 \pm 0.62$ & 4.58 to 4.73 & 44.83 \\
\hline PrAnL (Pre-anal length) & 3.20 & 6.60 & 4.70 & $4.81 \pm 0.64$ & 4.73 to 4.89 & 45.52 \\
\hline PoAnL(Post-anal length) & 5.70 & 11.00 & 8.20 & $8.13 \pm 1.07$ & 7.996 to 8.6 & 75.86 \\
\hline BW(Body weight)* & 7.89 & 64.00 & 13.14 & $26.52 \pm 10.68$ & 25.18 to 27.87 & - \\
\hline
\end{tabular}

$n$, sample size; Min, minimum; Max, maximum; SD, standard deviation; CL, confidence limit for mean value; $\mathrm{BW}$, body weight; *, weight in $\mathrm{g}$. 
The regression parameters $a$ and $b, 95 \%$ confidence limit and coefficients of determination $\left(r^{2}\right)$ for LWRs of A. testudineus were documented in Table 3 and Fig. 3. All LWRs were highly significant $(p<0.0001)$ with $r_{s}$ values $\geq 0.901$. Based on $r^{2}$ and $r_{s}$ value, LWR by BW vs. TL was the best fitted model among the ten equations.

Table 3. Descriptive statistics and estimated parameters of length-weight relationships of Anabas testudineus ( $n=454)$ captured from the Gajner Beel, NW Bangladesh

\begin{tabular}{|lccccccc|}
\hline \multicolumn{1}{|c}{ Equation } & \multicolumn{2}{c}{$\begin{array}{c}\text { Regression } \\
\text { parameter }\end{array}$} & \multicolumn{1}{c}{ 95\% CL of $\boldsymbol{a}$} & $\mathbf{9 5 \%} \mathbf{C L}$ of & $\boldsymbol{r}^{2}$ & $\boldsymbol{r}_{s}$ \\
\hline $\mathbf{B W}=\boldsymbol{a} \times \mathbf{T L}^{\boldsymbol{b}}$ & 0.0164 & 3.07 & 0.0136 to 0.0198 & 2.99 to 3.15 & 0.961 & 0.980 \\
\hline $\mathbf{B W}=\boldsymbol{a} \times \mathbf{S L}^{\boldsymbol{b}}$ & 0.0353 & 3.04 & 0.0287 to 0.0434 & 2.94 to 3.13 & 0.941 & 0.969 \\
\hline $\mathbf{B W}=\boldsymbol{a} \times \mathbf{H L}^{\boldsymbol{b}}$ & 1.4377 & 2.84 & 1.2180 to 1.6971 & 2.69 to 3.00 & 0.827 & 0.901 \\
\hline $\mathbf{B W}=\boldsymbol{a} \times \mathbf{P r D L}^{\boldsymbol{b}}$ & 1.4242 & 2.62 & 1.2330 to 1.6450 & 2.49 to 2.76 & 0.864 & 0.910 \\
\hline $\mathbf{B W}=\boldsymbol{a} \times \mathbf{P o D L}^{\boldsymbol{b}}$ & 0.0571 & 2.96 & 0.0474 to 0.0687 & 2.87 to 3.05 & 0.945 & 0.969 \\
\hline $\mathbf{B W}=\boldsymbol{a} \times \mathbf{P c L}^{\boldsymbol{b}}$ & 0.6556 & 3.34 & 0.5462 to 0.7868 & 3.17 to 3.51 & 0.865 & 0.914 \\
\hline $\mathbf{B W}=\boldsymbol{a} \times \mathbf{P v L}^{\boldsymbol{b}}$ & 0.8264 & 2.87 & 0.6979 to 0.9786 & 2.73 to 3.01 & 0.867 & 0.923 \\
\hline $\mathbf{B W}=\boldsymbol{a} \times \mathbf{A n s L}^{\boldsymbol{b}}$ & 0.3032 & 2.87 & 0.2544 to 0.3614 & 2.76 to 2.99 & 0.909 & 0.958 \\
\hline $\mathbf{B W}=\boldsymbol{a} \times \mathbf{P r A n L}^{\boldsymbol{b}}$ & 0.2741 & 2.88 & 0.2282 to 0.3294 & 2.76 to 2.99 & 0.906 & 0.950 \\
\hline $\mathbf{B W}=\boldsymbol{a} \times \mathbf{P o A n L}^{\boldsymbol{b}}$ & 0.0487 & 2.98 & 0.0407 to 0.0583 & 2.89 to 3.07 & 0.950 & 0.973 \\
\hline
\end{tabular}

$n$, sample size; $a$ and $b$ are the regression parameters of LWRs; CL, confidence intervals; $r^{2}$, co-efficient of determination. 

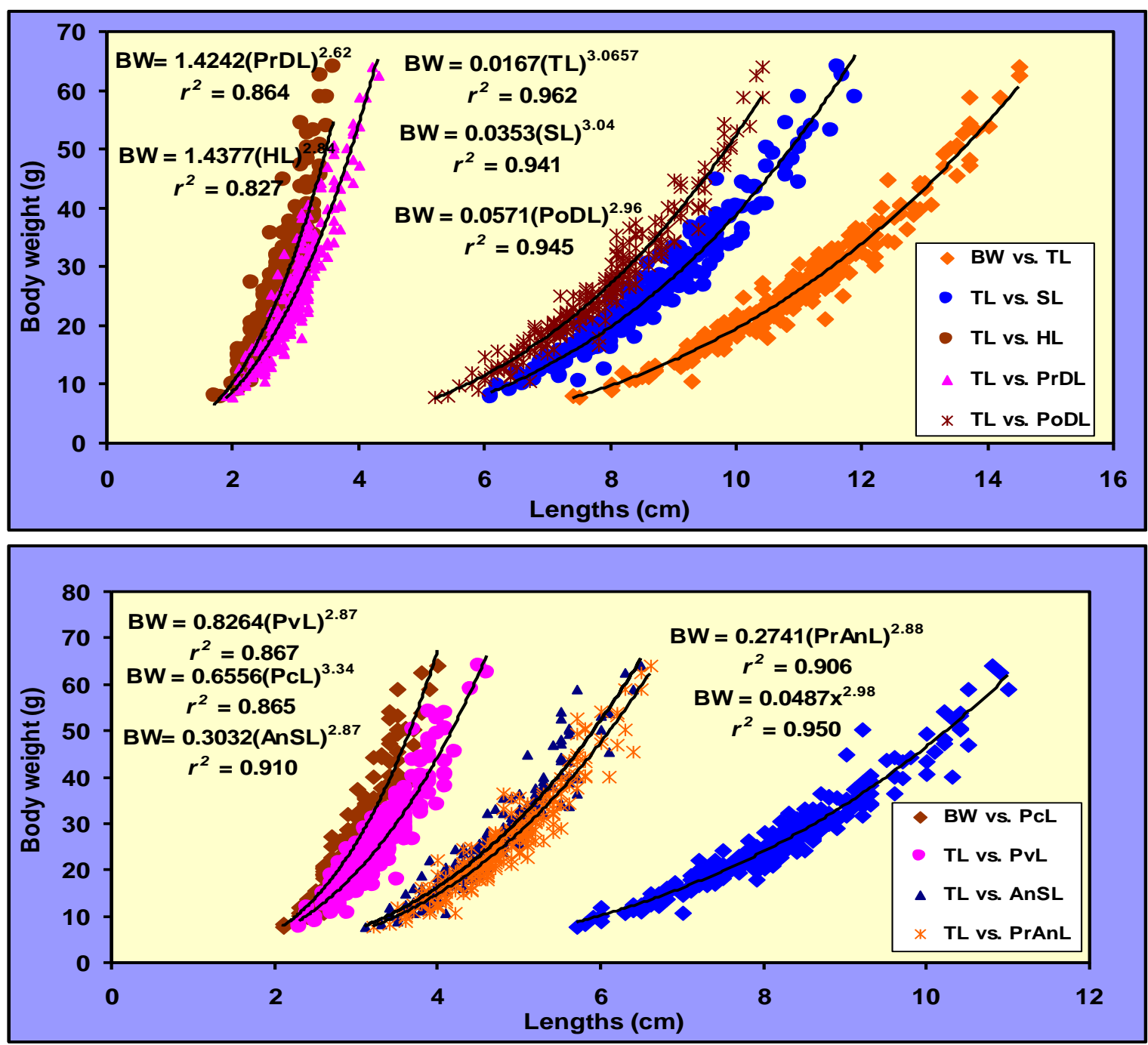

Fig. 3. Relationships $\left(\mathrm{BW}=\mathrm{a} \times \mathrm{L}^{b}\right)$ between lengths $v s$. body weight of male (lower) and female (upper) Anabas testudineus in the Gajner Beel.

The LLRs were shown in Table 4 and Fig. 4. All relationships were also highly correlated $(p<0.0001)$ with $r_{s}$ values $\geq 0.909$ (Spearman rank test). On the basis of maximum $r^{2}$ and $r_{s}$ value, LLR by TL $v s . S L$ and TL $v s$. PoAnL was the best fitted model among nine equations. 
Table 4. Descriptive statistics and estimated parameters of length-length relationships of Anabas testudineus $(n=454)$ captured from the Gajner Beel, NW Bangladesh

\begin{tabular}{|l|cccccc|}
\hline \multicolumn{1}{|c}{ Equation } & \multicolumn{2}{c}{$\begin{array}{c}\text { Regression } \\
\text { parameter }\end{array}$} & $\mathbf{9 5 \%} \mathbf{C L}$ of $\boldsymbol{a}$ & $\mathbf{9 5 \%} \mathbf{C L}$ of & $\boldsymbol{r}^{2}$ & $\boldsymbol{r}_{\boldsymbol{s}}$ \\
& $\boldsymbol{a}$ & $\boldsymbol{b}$ & & $\boldsymbol{b}$ & & \\
\hline $\mathbf{T L}=\boldsymbol{a}+\boldsymbol{b} \times \mathbf{S L}$ & 0.2744 & 1.22 & 0.0163 to 0.5325 & 1.19 to 1.25 & 0.965 & 0.981 \\
\hline $\mathbf{T L}=\boldsymbol{a}+\boldsymbol{b} \times \mathbf{H L}$ & 0.7320 & 3.71 & 0.1755 to 1.2886 & 3.51 to 3.91 & 0.844 & 0.909 \\
\hline $\mathbf{T L}=\boldsymbol{a}+\mathbf{b} \times \mathbf{P r D L}$ & 1.7268 & 3.06 & 1.2857 to 2.1680 & 2.92 to 3.21 & 0.876 & 0.918 \\
\hline $\mathbf{T L}=\boldsymbol{a}+\mathbf{b} \times \mathbf{P o D L}$ & 0.4787 & 1.33 & 0.2150 to 0.7423 & 1.30 to 1.37 & 0.962 & 0.975 \\
\hline $\mathbf{T L}=\boldsymbol{a}+\mathbf{b} \times \mathbf{P c L}$ & -0.7796 & 3.92 & -1.3440 to -0.2150 & 3.73 to 4.11 & 0.874 & 0.920 \\
\hline $\mathbf{T L}=\boldsymbol{a}+\mathbf{b} \times \mathbf{P v L}$ & 0.9472 & 3.02 & 0.4637 to 1.4307 & 2.88 to 3.17 & 0.873 & 0.924 \\
\hline $\mathbf{T L}=\boldsymbol{a}+\mathbf{b} \times \mathbf{A n s L}$ & 0.8670 & 2.15 & 0.4842 to 1.2499 & 2.07 to 2.23 & 0.918 & 0.957 \\
\hline $\mathbf{T L}=\boldsymbol{a}+\mathbf{b} \times \mathbf{P r A n L}$ & 0.9007 & 2.07 & 0.5139 to 1.2876 & 1.99 to 2.15 & 0916 & 0.953 \\
\hline $\mathbf{T L}=\boldsymbol{a}+\mathbf{b} \times \mathbf{P o A n L}$ & 0.4844 & 1.28 & 0.2429 to 0.7260 & 1.25 to 1.31 & 0.968 & 0.983 \\
\hline
\end{tabular}
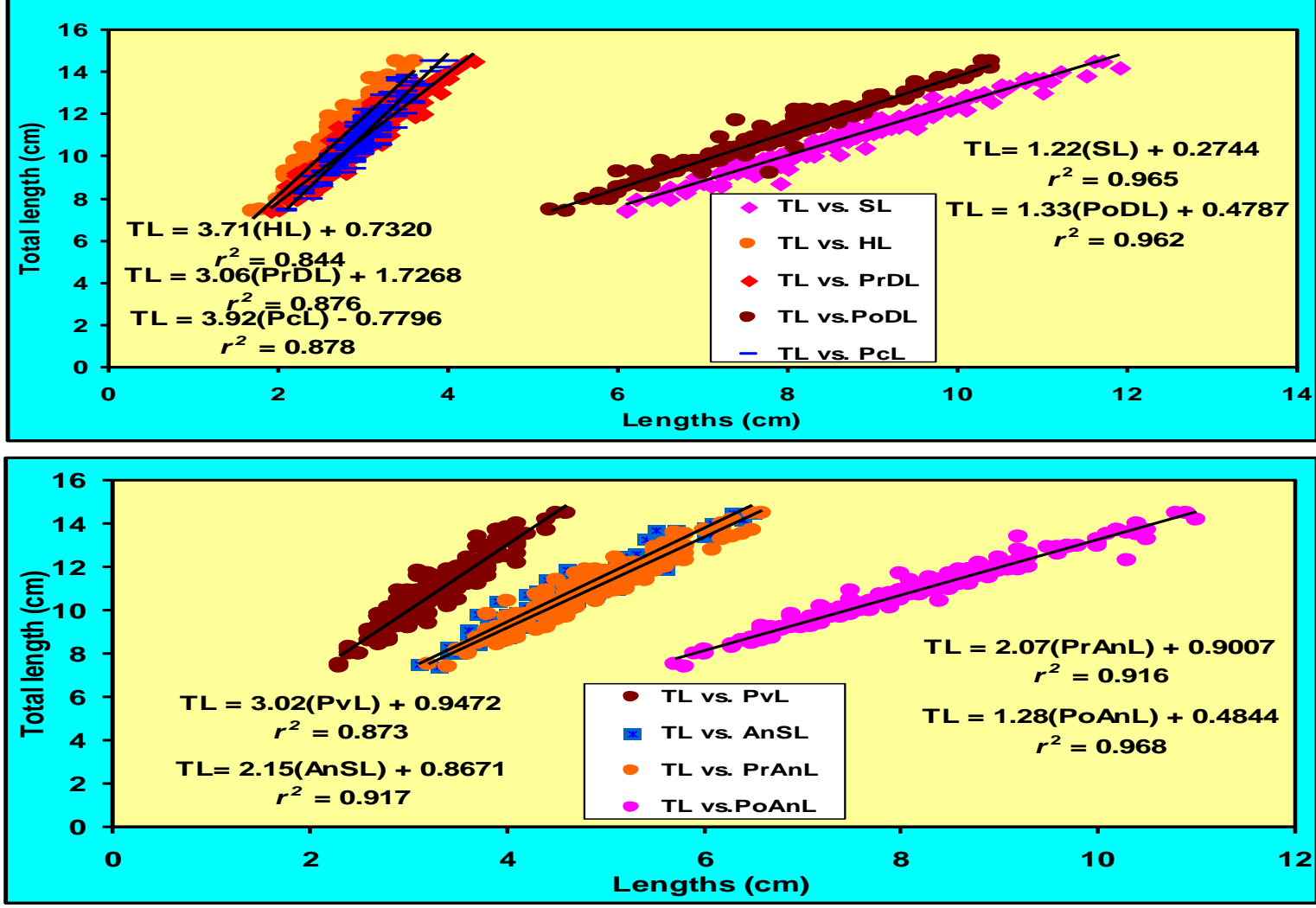

Fig. 4. Relationships $\left(\mathrm{TL}=\mathrm{a}+b^{*} \mathrm{~L}\right)$ between length $v s$. length of male and female Anabas testudineus Gajner Beel. 


\section{Meristic characteristics}

The body shape of $A$. testudineus was oblong, moderately deep and compressed. Body color was greenish brown or blackish brown. Mouth was anterior with villiform teeth on jaws and the lower jaw was slightly longer. Dorsal and anal fin were long, pectoral and caudal fin is rounded. Dorsal fin, pelvic fin and anal fin rays were modified to spine. Lateral line was interrupted; the first lateral line contained 14-17 scales and the second 10-13 scales. Body covered with ctenoid large scales arranged regularly. The observed fin formula of A. testudineus was dorsal, D. 26-28 (XVI-XVIII 1-2/7-10); pectoral, $\mathrm{P}_{1}$. 13-15(1-2/11-14); pelvic, $\mathrm{P}_{2} .6$ (I5); anal, A. 18-21 (VIII-XI1 2/8-10); caudal, C.15-17(2/13-15) respectively (Table 5 \& Fig. 5).

Table 5. Meristic counts of Anabas testudineus $(n=454)$ captured from the Gajner Beel, NW Bangladesh

\begin{tabular}{|lcccc|}
\hline Meristic data & Numbers & Spine & Unbranched & Branched \\
\hline Dorsal fin rays & $26-28$ & XVI-XVIII & $1-2$ & $7-10$ \\
\hline Pectoral fin rays & $13-15$ & - & $1-2$ & $11-14$ \\
\hline Pelvic fin rays & 6 & I & - & 5 \\
\hline Anal fin rays & $18-21$ & VIII-XI & $1-2$ & $8-10$ \\
\hline Caudal fin rays & $15-17$ & - & 2 & -15 \\
\hline $\mathbf{1}^{\text {st }}$ lateral line scale & $14-17$ & - & & - \\
\hline $\mathbf{2}^{\text {nd }}$ lateral line scale & $10-13$ & & - & - \\
\hline $\begin{array}{l}\text { Scale above the lateral } \\
\text { line to dorsal fin base }\end{array}$ & $3-4$ & - & - \\
\hline $\begin{array}{l}\text { Scale below the lateral } \\
\text { line to pelvic fin base }\end{array}$ & $6-7$ & & & \\
\hline
\end{tabular}

$n$, sample size; Unbranched, single fin ray; Branched, upper portion of fin is divided into several rays; Spine, upper portion of unbranched fin ray is pointed. 

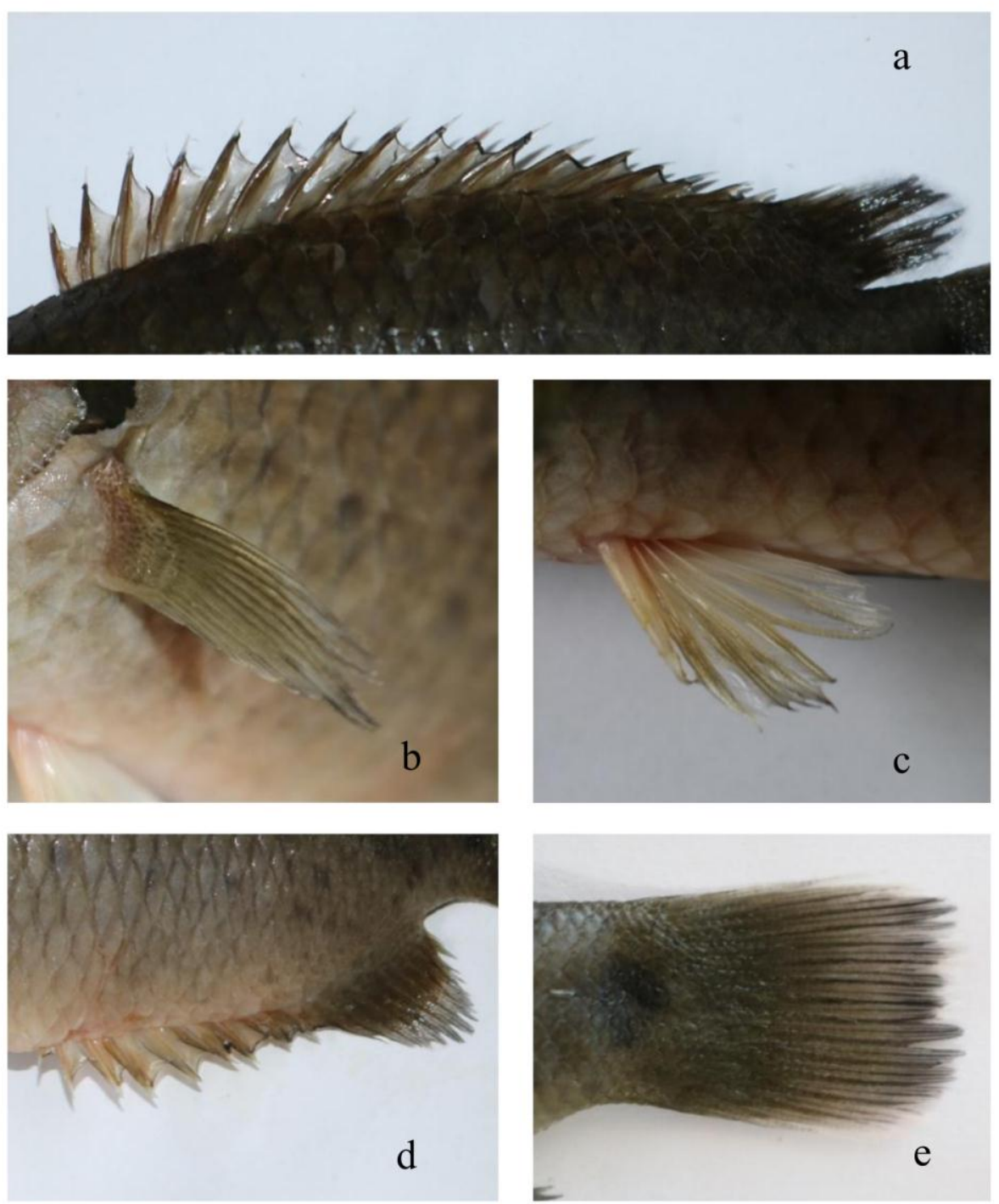

Fig. 5. Different fins such as (a) Dorsal, (b) Pectoral, (c) Pelvic, (d) Anal and (e) Caudal of Anabas testudineus from the Gajner Beel.

\section{DISCUSSION}

Although some authors have been working on some biological aspects (Hubbs and Lagler, 1958; Hassan et al., 2005; Alam et al., 2007) of A. testudinesus but this is the first study which estimates the relative growth using ten linear dimensions and also studies the meristic features. A total of 244 individuals comprised altered body sizes were used for the current study and the recorded maximum length was $14.50 \mathrm{~cm}$ TL, which is moderately similar with Hassan et al. (2005) who recorded TL as $14.20 \mathrm{~cm}$ in the Chittagong region but is lower than the maximum length reported by Shafi and Quddus (1982), Talwar and Jhingran (1991) and Rahman (2005) (22.00 cm, TL 25.00 $\mathrm{cm}$ and $17.60 \mathrm{~cm}$, respectively). Maximum length is helpful for the estimation of growth 
parameters that is needed for planning of fisheries capital and sustainable management (Ahmad et al., 2012).

In our present study, the allometric co-efficient, $b$ value was ranged from 2.623.34 which is in the limit reported by Froese (2006) (2.50-3.50) and Carlender (1969) (2.00-4.00). According to Tesch (1971), $b=3$, means the growth isometric and $b>3$, means the growth is positive allometric and $b<3$, means the growth is negative allometric. Shafi and Mustafa (1976) and Hossain et al. (2015b) reported $b$ value as 2.72 and 2.9 from Dhaka Bangladesh and Tetulia River, southern Bangladesh, respectively. However, the values of $b$ may divers because of differences growth of organs, sex and preservation process and variation in the physiology (Hossain et al., 2012b; 2015b), which were not observed in the current study. Furthermore, LLRs were highly correlated $(P<0.001)$.

In the current study, the observed spine fin rays (16-17) in dorsal fin rays were similar to Shafi and Quddus (1982), Talwar and Jhingran (1991) and Rahman (2005) as well as soft fin rays (7-10) is similar with Shafi and Quddus (1982), pectoral fin contained 13-15rays and pelvic fin (Riede, 2004) that was more or less similar to the findings of Bhuiyan (1964), Shafi and Quddus (1982), Talwar and Jhingran (1991) and Rahman (2005). Anal fin (18-21) is disparate with their study Caudal fin is somewhat similar to the number reported Shafi and Quddus (1982). However, no one mentions spine and unbranched fin rays separately but the present study does that. First lateral line containing 14-17 scales was similar (16-17) with the results of Rahman (2005) and the second (10-13 scales) deviated from Rahman (2005). Meristic counts of the current study were done in pictorial form which helps to easily identify this species and comparable with the future study. Above lateral line (3-4) scales was similar to the findings of Rahman (2005) but the below lateral line scales (6-7) differ with the findings Rahman (2005).

\section{CONCLUSION}

These findings will help to more accurately understand the growth pattern of Anabas testudines and serve as baseline data for this species, a wetland ecosystem Gajner Beel, and nearby ecosystem for evaluation with future studies of this fish.

\section{ACKNOWLEDGMENTS}

The authors extend their sincere appreciation to the PIU-BARC, NATP-2, SubProject ID: 484 for funding the project (Management of indigenous fishes in the wetland (Gajner Beel, Pabna) ecosystem) and it is a partial work of this CRG (Competitive Research Grants) Project. 


\section{REFERENCES}

Ahmed, Z. F.; Hossain, M. Y. and Ohtomi, J. (2012). Modeling the growth of Silver hatchet chela Chela cachius (Cyprinidae) from the Old Brahmaputra River in Bangladesh using multiple functions. Zoological Studies, 51: 336-344.

Alam, J.; Mustafa, G. and Islam, M. (2010). Effects of some artificial diets on the growth performance, survival rate and biomass of the fry of climbing perch, Anabas testudineus (Bloch, 1792). Natural Science, 8: 36-42.

Alam, M. A.; Noor, A. M.; Khan, M. M. R. and Rahman, L. (2007). Growth performance and morphological variations of local and Thai climbing perch (Anabas testudineus, Bloch). Fisheries Research, 11: 163-171.

Alleng, R. (1991). Field guide to the freshwater fishes of New Guinea Christensen Research Institute, Madang, Papua New Guinea, 9: 268.

Atack, K. (2006). A Field Guide to the Fishes of Kuching Rivers, Sarawak, Malaysian Borneo. Natural History Publications (Borneo), Kota Kinabalu.

Be, N. V.; Giao, N. T. and Dan,T. H. (2017). Water quality in intensive Climbing perch ponds (Anabas testudineus) and suggestion for better management of wastewater discharge. Imperial Journal of Interdisciplinary Research, 3(9):665-671.

Beacham, T. D. (1990). A genetic analysis of meristic and morphometric variation in chum salmon (Oncorhynchus keta) at three different temperatures. Canadian Journal of Zoology, 68: 225-229.

Bhuiyan, A. L. (1964). Fishes of Dacca. Asiatic Soc. Pakistan, Publ. No. 13, Dacca, p 109

Carlander, K. D. (1969).Handbook of freshwater fishery biology. vol. 1. The Iowa State University Press. Ames, IA, p 752

Collins, R. A.; Britz, R. and Ruber, L. (2015). Phylogenetic systematics of leaf fishes (Teleostei: Polycentridae, Nandidae)". Journal of Zoological systematics and Evolutionary Research, 53 (4): 259-272.

Czerwinski I. A.; Gutiérrez-Estrada J. C.; Soriguer, M. C. and Hernando, J. (2008) Morphometric relations for body size and mouth dimensions For four fish species in the strait of Gibraltar acta ichthyologica et Piscatoria 38 (2): 81-90 
Doherty, D. and Mc-Carthy, T. K. (2004). Morphometric and meristic characteristics analyses of two western Irish populations of Arctic Char, Salvelinusalpinus (L.). Proceedings of the Royal Irish Academy B 104: 75-85.

Froese, R. (2006). Cube law, condition factor and weight-length relationships: History, meta-analysis and recommendations. Journal of Applied Ichthyolology, 22: 241253.

Froese, R. and Pauly D. (Eds.) (2020) Fish Base world wide web electronic publication. Available at: http://www.fishbase.org (Accessed on: 22 February 2020)

Froese, R. and Pauly, D. (Eds.) (2019). "Anabantidae" in FishBase. Available at: http://www.fishbase.org (Accessed on 22 July 2019)

Garcia, L. M. B. (2010). Species composition and length-weight relationship of fishes in the Candaba wetland on Luzon Island, Philippines, 26_(6): 946-948.

Ghani, I. M. M. and Ahmad, S. (2011). Comparison methods of multiple linear regressions in fish landing." Australian Journal of Basic and Applied Sciences, $5(1): 25-30$.

Gonçalves, J. M. S.; Bentes L. and Lino P. G. (1997). Fish mouth dimensions and size selectivity in a Portuguese long line fishery. Journal of Applied Ichthyology, 13: $41-44$

Hassan, M. M.; Khan, M. G. Q. and Hasanat, M. A. (2005). Taxonomic comparison of the populations of climbing perch, Anabas testudineus (Bloch) in Bangladesh. Journal of Bangladesh Agricultural University, 3 (2): 297-302.

Hassan, H. U.; Ali, Q. M.; Rahman, M. A.; Kamal, M.; Tanjin, S.; Farooq, U.; Mawa, Z.; Badshah, N.; Mahmood, K.; Hasan, M. R.; Gabool, K.; Rima, F. A.; Islam, M. A.; Rahman, O. and Hossain, M. Y. (2020). Growth pattern, condition and prey-predator status of 9 fish species from the Arabian Sea (Baluchistan and Sindh), Pakistan. Egyptian Journal of Aquatic Biology \& Fisheries, 24: $281-292$.

Hasan, M. R., Mawa, Z., Hassan, H.U., Rahman, M. A., Tanjin, S., Ahmed, A. N., Gabol, Karim., Basar M. A., Jasmine, S., Ohtomi, J. and Hossain, M.Y. (2020). Impact of eco-hydrological factors on growth of the Asian stinging catfish 
Heteropneustus fosslis (Bloch, 1794) in a wetland ecosystem. Egyptian Journal of Aquatic Biology and Fisheries, 24(5): 77-94.

Hossain, M. Y.; Hossen, M. A.; Pramanik, M. N. U.; Ahmed, Z. F.; Yayha, K.; Rahman, M. M. and Ohtomi, J. (2015a). Threatened fish of world: Anabas testudineus (Bloch, 1792) (Perciformes: Anabantidae). Croatian Journal of Fisheries, 73:128-131.

Hossain, M. Y.; Jewel, M. A. S.; Nahar, L.; Rahman, M. M.; Naif ,A. and Ohtomi, J. (2012b). Gonadosomatic index-based size at first sexual maturity of the catfish Eutropiichthys vacha (Hamilton, 1822) in the Ganges River (NW Bangladesh). Journal of Applied Ichthyology, 28: 601-605.

Hossain, M. Y.; Rahman, M. M.; Fulanda, B.; Jewel, M. A. S.; Ahamed, F. and Ohtomi J. (2012a). Length-weight and length-length relationships of five threatened fishes from the Jamuna (Brahmaputra River distributary) River, northern Bangladesh. Journal of Applied Ichthyology, 28: 275-277.

Hossain, M. Y.; Sayed, S. R. M.; Rahman, M. M.; Ali, M. M.; Hossen, M. A.; Elgorban, A. M.; Ahmed, Z. F. and Ohtomi, J. (2015b). Length-weight relationships of nine fish species from the Tetulia River, southern Bangladesh. Journal of Applied Ichthyology, 31: 967-969.

Hubbs, C. L. and Lagler, K. F. (1958). Fishes of the Great Lakes region. 2nd ed. Cranbrook Institute of Science Bulletin 26: 1-213

IUCN, Bangladesh (2015). Red List of Bangladesh Volume 5: Freshwater Fishes. IUCN, International Union for Conservation of Nature, Bangladesh Country Office, Dhaka, Bangladesh xvi+360

IUCN. (2020). IUCN Red List of Threatened Species, Version 2020-2. Downloaded on 19 April 2020

Islam, M.A.; Mawa, Z.; Hossain, M.Y.; Rahman, M.A.; Hasan, M.R.; Khatun, D.; Chowdhry, A.A.; Rahman, O.; Rahman, M.A.; Tanjin, S.; Hassan, H.U. and Ohtomi, J. (2020). Morphometric and meristic characteristics of Spotted snakehead Channa punctata (Bloch, 1793) in a wetland ecosystem (NW Bangladesh) using multi-linear dimensions. Indian Journal of Geo-Marine Science, 49(8): 1442-1446. 
Jannat, K. M.; Rahman, M. M.; Bashar, M. A.; Hasan, M. N.; Ahamed, F. and Hossain, M. Y. (2012). Effects of Stocking Density on Survival, Growth and Production of Thai Climbing Perch (Anabas testudineus) under Fed Ponds. Sains Malaysia, 41 (10): 1205-1210.

Jayasankar P.; Thomas P. C.; Paulton M. P. and Mathew J. (2004). Morphometric and genetic analyzes of Indian mackerel (Rastrelliger kanagurta) from peninsular India. Asian Fisheries Science, 17: 201-215.

Khatun, D.; Hossain, M. Y.; Rahman, M. A.; Islam, M. A.; Rahman, O.; Azad, M. A. K.; Sharmin, M. S.; Parvin, M. F.,; Haque, A. T. U.; Mawa, Z. and Hossain, M, A. (2019). Life-history traits of the Climbing perch Anabas testeudineus (Bloch, 1792) in a wetland ecosystem. Jordan Journal of Biological Sciences, 12: 175-182.

Keddy, P. A. (2010). Wetland ecology: principles and conservation (2nd ed.). New York: Cambridge University Press. ISBN 978-0521519403

Kohinoor, A. H. M.; Jahan, D. A.; Khan, M. M.; Ahmed. S. U. and Hussain, M. G. (2009). Culture potentials of climbing perch, Anabas testudineus (Bloch) under different stocking densities at semi-intensive management. Bangladesh Journal of Fisheries Research, 13:115-120.

Kottelat, M. (2001). Fishes of Laos. WHT Publications Ltd, Colombo.

Kumar, K.; Lalrinsanga, P. L.; Sahoo, M.; Mohanty, U. L.; Kumar, R. and Sahu, A. K. (2013). Length-weight relationship and condition factor of Anabas testudineus and Channa species under different culture systems, World Journal of Fish and Marine Science 5: 74-78.

Le Cren, (E.D.) (1951). The length-weight relationship and seasonal cycle in gonad weight and condition in the perch (Perca fluviatilis). Journal of Animal Ecology, 201-219.

Lourie, S. A.; Pritchard, J. C.; Casey, S. P.; Truong, S. K.; Hall, H. J. and Vincent, A. C. J. (1999). The taxonomy of Vietnam's exploited seahorses (Family Syngnathidae). Biological Journal of the Linnaean Society, 66: 231-256. 
Marimuthu, K.; Arumugam, J.; Sandragasan, D. and Jegathambigai, R. (2009). Studies on the fecundity of native fish climbing perch (Anabas testudineus, bloch) in Malaysia. American Eurasian Journal of Sustainable Agriculture, 3: 266-274.

Mazid, M. A.; Rahman, M. J. and Mustafa, M. G. (2005). Abundance, migration and management of Jatka (juvenile hilsa, Tenualosa ilisha) in the Gajner Beel, Pabna, Bangladesh. Bangladesh Journal of Fisheries Research, 9: 191-202.

Menon, A. G. K. (1999) Check list-fresh water fishes of India. Records of zoological survey of India, 175: 366.

Morioka, S.; Ito, S.; Kitamura, S. and Vongvichith, B. (2009). Growth and morphological development of laboratory-reared larval and juvenile climbing perch Anabas testudineus, Ichthyological Research 56 (2): 16

Murphy, C. E.; Hoover, J. J.; George, S. G. and Killgore, K. J., (2007). Morphometric variation among river sturgeons (Scaphirhynchus spp.) of the Middle and Lower Mississippi River. Journal of Applied Ichthyology, 23: 313323.

Mustakim, M.; Anggoro, S.; Purwanti, F. and Haeruddin, (2019). Length-weight relationships and condition factor of Anabas testudineus in the Semayang Lake, East Kalimantan, Indonesia. Aquaculture, Aquarium, Conservation \& Legislation; Cluj-Napoca 12 (1): 327-337.

Nagris, A. and Hossain, M. A. (1987). Food and feeding habits of Koi fish (Anabas testudineus Bloch). Bangladesh Journal of Agriculture, 12: 121-127.

Nelson, J. S.; Grande, T. C.; Wilson, M. Y. (2016). Fishes of the World. John Wiley \& Sons.

Pandey, A.; Srivastava, P. K; Adhikari, S. and Singh, D. K. (1992). pH profile of gut as an index of food and feeding habits of fishes. Journal of Freshwater Biology 4, 75-79.

Park, J. M. and Huh, S. H. (2015). Length-weight relations for 29 demersal fishes caught by small otter trawl on the south-eastern coast of Korea. Acta Ichthyologica et Piscatoria, 4 (4): 427-431. 
Prasanth, P. S. (2006). Influence of variations in habitat on the feeding behavior and reproductive strategies of climbing perch (Anabas testudineus) a freshwater fish. MSc, Dissertation, University of Calicut, India.

Rahman, A. K. A. (1989) Freshwater fishes of Bangladesh. Zoological Society of Bangladesh. Department of Zoology, University of Dhaka, p364

Rahman, A. K. A. (2005). Freshwater fishes of Bangladesh. Second edition. Zoological Society of Bangladesh (ZSB), University of Dhaka, Dhaka, Bangladesh, p 394

Rahman, A.; Talukdar, K.; Rahman, W. and Deka, P. (2015). Length-Weight relationship and relative condition factor of Anabas testudineus (Bloch) of Deepar Beel (wetland) of Assam. Indian Institute of Journal of Applied Research, 1 (11): 956-958.

Rainboth, W. J. (1996) Fishes of the Cambodian Mekong. FAO Species Identification Field Guide for Fishery Purposes. FAO, Rome, p 265

Ramsar conservasion (1971). Official page of the Ramsar Convention". Retrieved 2011-09-25.10, 36(1):85-90.

Riede, K . (2004) Global register of migratory species - from global to regional scales. Final Report of the R \& D-Project 80805 081. Federal Agency for Nature Conservation, Bonn, Germany, p 329

Sandoval-Huerta, E. R.; Madrigal-Guridi. X.; DomínguezDomínguez, O.; RuizCampos, G. and González-Acosta A. F. (2015). Length-weight and lengthlength relations for 14 fish species from the central Mexican Pacific coast. Acta Ichthyologica et Piscatoria 45 (2): 199-201.

Sarma, K.; Pal, A. K.; Ayyappan, S.; Das, T.; Manush, S. M.; Debnath, D. and Baruah, K. (2010). Acclimation of Anabas testudineus (Bloch) to three test temperatures influences thermal tolerance and oxygen consumption Fish Physiology and Biochemistry, 36: 85-90.

Satrawaha, R. and Pilasamorn, C. (2009). Length-weight and length-length relationships of fish species from the Chi River, northeastern Thailand. Journal of Applied Ichthyology, 25 (6): 787-788. 
Shafi, M. and Mustafa, G. (1976). Observations on some aspects of the biology of the climbing perch, Anabas testudineus (Bloch) (Anabantidae: Perciformes). Bangladesh Journal of Zoology, 4 (1): 21-28.

Shafi, M. and Quddus, M. M. A. (1982). Bangladesher Mathso Shampad (Fisheries of Bangladesh) (1sted.). Bangla Academy, Dacca, Bangladesh, p 444

Talwar, P. K. and Jhingran, A. G. (1991). Inland fishes of India and adjacent countries. Volume 1 and 2. Oxford IBH Publishing Co Pvt Ltd, New DelhiCalcutta, p 1158

Tan, H. H. and Lim, K. K. P. (2004). Inland fishes from the Anambas and Natuna Islands, South China Sea, with description of a new species of Betta (Teleostei: Osphronemidae). Supplement Raffles Bulletin of Zoology, 11: 107-115.

Vidthayanon, C. (2002). Peat swamp fishes of Thailand. Office of Environmental Policy and Planning, Bangkok, Thailand, p 136.

Wang, T. Y.; Tzeng, C. S. and Shen, S. C. (1999). Conservation and phylogeography of Taiwan paradise fish, Macropodus opercularis Linnaeus. Acta Zoologica Taiwan, 10: $121-134$.

Zalina, I.; Saad, C .R.; Rahim, A. A.; Christianus, A. and Harmin, S. A. (2011). Breeding performance and the effect of stocking density on $\mathrm{n}$ the growth and survival of climbing perch Anabas testudineus. Journal of Fish Aquatic Science, 6: 834-839.

Ziauddin, G.; Behera, S.; Sanjeev, K.; Rinku, G.; Jomang, O. and Baksi, S. (2016). Morphometrical and gonadal studies of a threatened fish, Anabas testudineus with respect to seasonal cycle. Internation Journal of Fish Aquacultural Science 6: 714. 